\title{
Collaborative Networks as a Source of Innovation and Sustainable Competitiveness for Small and Medium Food Processing Enterprises in Indonesia
}

\author{
Mukhamad Najib ${ }^{1}$, Farida Ratna Dewi ${ }^{1} \&$ Hardiana Widyastuti ${ }^{1}$ \\ ${ }^{1}$ Department of Management, Faculty of Economics and Management, Bogor Agricultural University (IPB), \\ Indonesia \\ Correspondence: Mukhamad Najib, Department of Management, Faculty of Economics and Management, Bogor \\ Agricultural University (IPB), Indonesia. E-mail: najib@ipb.ac.id
}

Received: January 7, 2014

Accepted: July 1, 2014

Online Published: August 22, 2014

doi:10.5539/ijbm.v9n9p147

URL: http://dx.doi.org/10.5539/ijbm.v9n9p147

\begin{abstract}
Collaborative Networks give an opportunity to Small and Medium Enterprises to conduct the learning process, transfer knowledge and technology, and increase organizational capacity as a pre-requisite for sustainable innovation development. The aim of this study is to discover the relationships between Collaborative Networks and Innovation, between Innovation and Competitiveness, and between Collaborative Networks and Competitiveness. This study used the Structural Equation Modelling with Partial Least Square as the tool for analysis. Forty respondents were interviewed. The respondents were food-processing Small and Medium Enterprises which had innovations and were located in Bogor, Sukabumi, and Bandung District.The results of the study showed that Collaborative Networks influence innovation but do not have significant effect on sustainable competitiveness, whereas the innovations done by Small and Medium Food Processing Enterprises in West Java will increase sustainable competitiveness.
\end{abstract}

Keywords: collaborative networks,sustainable competitiveness, innovation, small and medium enterprises

\section{Introduction}

The ever-increasing competitive dynamics demand the Indonesian Small and Medium Enterprises (SMEs) build their competitiveness continuously as a pre-requisite for ensuring the continuation of their businesses. One of the important determining factors of competitiveness is the periodic development of new products which can fulfill the market's demands. According to Datar et al. (1997), the companies which are able to offer new high-quality products to the market faster than their competitors will receive a larger economic profit. In this case, the companies must innovate continuously in order to maintain its competitiveness sustainably.

Innovation as an effective competition tool needs adequate human resources, financial resources, and technology. Rapid changes in technology often force the companies to rely on outside technological knowledge and skills. Small and Medium Enterprises as business units which have many financial limitations find it difficult to finance their own innovation development process. Therefore, Collaborative Networks are an important tool for Small and Medium Enterprises in order to develop their innovation amidst their limited resources.

Collaborative Networks gives an opportunity to Small and Medium Enterprises to conduct the learning process, transfer knowledge and technology, and increase organizational capacity as a pre-requisite for sustainable innovation development. Based on the description above, Collaborative Networks and Innovation have great potential in describing the creation of Small and Medium Enterprises' competitiveness in Indonesia due to the fact that the profile of Small and Medium Enterprises in Indonesia is limited in human resources, financial resources, and technology.

The creation of sustainable Small and Medium Enterprises competitiveness in Indonesia needs to be quickly formulated because the escalating level of competitiveness as globalization takes root, especially after the establishment of the ASEAN-China Free Trade Agreement, where the influx of products from China in particular and from other ASEAN countries in general have caused many Small and Medium Enterprises to go bankrupt. 
Up to this day, very few researches in Indonesia have tried to discover the relationships between the variables of Collaborative Networks, Innovation, and Sustainable Competitiveness, especially in the context of Small and Medium Enterprises. This study which will be conducted is paramount in discovering a valid answer about the role that Collaborative Networks and Innovation play in creating sustainable competitivenessin Small and Medium Enterprises in Indonesia. Through the discovery of the relationships between those variables, this study contributes in the development of Small and Medium Enterprises in order to face the global market which becomes more and more competitive day the day. The purpose of this study is to discover what the relationship between Collaborative Networks and Innovation, between Innovation and Competitiveness, and between Collaborative Network and Competitiveness.

\section{Theoretical Background}

\subsection{Collaborative Networks and Innovation}

Collaborative Networks and partnership management are designed to determine the innovation strategy by assessing the competence of external network partners and universities, companies, and the Government in a single framework (Varrichio et al., 2012). Collaborative Networks are beneficial in increasing learning and innovationcapacity (Ceglie, 2003). The results of the study by Tsai (2009) show that collaboration with different partners will increase innovation because it represents the variety of knowledge shared. Sakamoto et al. (2010) stated that in the current market context wherein internal and external business dynamics have become more complex, companies improve their collaborative strategies which will force innovation so that it could generate a value in each of the members.

The Collaborative Networks model is adapted from the study by Tsai (2009) who developed a model for collaborative networks for innovation development. According to Tsai (2009), there are four variables which can explain collaborative networks: Suppliers, Clients, Competitors, and Research Organizations. Zeng et al. (2009) defined collaborative networks as a vertical network which consists of clients, suppliers, and other companies (competitors) and a horizontal network which consists of research institutions, universities, and government agents. The results of the study show that vertical collaborations have a more significant role in the innovation process compared to horizontal collaborations.

SMEs, especially in developing countries, should develop collaborative networks to improve their inovation since SMEs have several limitation such as financial, technology and humah resources. By developing collaborative networks, SMEs can get more resources for innovation.In the context of SMEs in Indonesia, it needs to be studied which partner can encourage Innovation. In this study, the effect of the five variables in Collaborative Networks, i.e.: the Suppliers, the Buyers, the Competitors, the Researchers, and the Government on innovationin food processing Small and Medium Enterprises will be examined.

\subsection{Inovation and Sustainable Competitiveness}

Nowadays, developing sustainable competitiveness becomes more difficult for SMEs in an emerging market country like Indonesia. Once the country opens its market to foreign products, the competitive pressure will increase. Innovation is needed by SMEs to deal with such situation. Many researchers believe that a company's competitivenessis affected by its ability to innovate (i.e., Sakamoto et al., 2010). According to Tsai (2009), when the intensity of the market's competitiveness increases, product innovation becomes more important. Of course compete with large producers is not easy for SMEs. As we know that large producers has competitive advantage from economic of scale so that their product becomes cheaper in the market. Therefore, to deal with this competitive environment, small enterprises must both innovate and minimize cost in order to have sustainable competitiveness (Hanna \& Walsh, 2002).

Innovation could become a source of competitiveness when the innovation developed by the company can create a product with higher value than its competitors (Hamdani \& Wirawan, 2012; Munir et al., 2011). In addition, Das (2013) stated that the performance of companies in the food industry is very much affected by innovation. These researches strengthen the premise in this study that Innovationis the most important factor in increasing competitiveness, even more important in Small and Medium Enterprises.

In order to measure the variable of innovation, this study adapted the innovation model developed by Sundbo (2003), where innovation could be assessed based on the three variables observed, product innovation, process innovation, and marketing innovation. Product innovation is defined as the introduction of new products to the market. Process innovation is the introduction of a new production process using a new technology or a new working method. Marketing innovation is defined as a company's new method for facing the market behavior such as new strategies, new marketing, new alliances, etc. 
In this study, innovation will be seen from product innovation, packaging innovation, production process innovation, and marketing aspect innovation.

\subsection{Collaborative Networks and Sustainable Competitiveness}

Small and Medium Enterprises can quickly respond to the market's demands through the modification of existing products by collaborating with the suppliers in facing the intense competitive pressure (Tsai, 2009). To develop competitivenessability, Small and Medium Enterprises can organize themselves through collaborative networks, paying attention to the variety of actors in their collaboration and finding the optimum solution in facing environmental pressure (Mezgar et al., 2000). According to Kolakovic \& Milovanovic (2010), the solution for facing challenges in Small and Medium Enterprises is collaborating with other organizations by building the right collaboration. The purpose of this strategy is to obtain competitiveness benefits that will be difficult to reach individually.

According to BarNir and Smith (2002), the ability to form constellations is a critical factor in determining competitive positions. Becoming a part of an alliance will give benefits to Small and Medium Enterprises which have limited resources and have limited existence in the market. Collaborative networks can be made by small enterprises within complex assemblies and they can maintain their competitive positions (Hanna \& Walsh, 2002). Collaborative networks with external parties need to be developed in order to assist manufacturing Small and Medium Enterprisesin strengthen their industrial competitiveness industry (Zeng et al., 2010). Competitiveness built upon collective within collaborative networks is hoped expected to be able to create sustainable competitiveness.

SMEs in Indonesia have a long experience of working together each other, especially in terms of production and marketing. However, the existence of SMEs in Indonesia is still not stable in the market. Collaborative networks should be expanded to other parties such as supplier, buyer, government and university. Such kinds of collaboration give benefit for SMEs to improve their innovation capability as necessary condition to develop sustainable competitiveness. The premise in this study is that Collaborative Networks have a correlation with Sustainable Competitiveness where the Sustainable Competitiveness variable reflects four observable variables, i.e. the environmental impact, the market share, the profit, and the social impact.

\subsection{Research Model and Hypotheses}

Based on the literature review above, a structural model was developed with three latent variables, Collaborative Network, Innovation, dan Sustainable Competitiveness. Collaborative Network is reflected by the collaboration with suppliers, buyers, competitors, researchers, and the government. Innovation is reflected by the four variables for innovation, i.e. packaging innovation, product innovation, process innovation, and marketing innovation. Sustainable Competitiveness is reflected by environmental impact, market share, profit, and social impact. The structural model developed in this study can be seen in Figure 1. The hypotheses developed in this study are:

H1: Collaborative networks have positive impact on Small and Medium Enterprises' innovation.

H2:Collaborative networks have a positive impact on Small and Medium Enterprises' sustainable competitiveness.

H3: Innovation has a positive impact on Small and Medium Enterprises' sustainable competitiveness. 


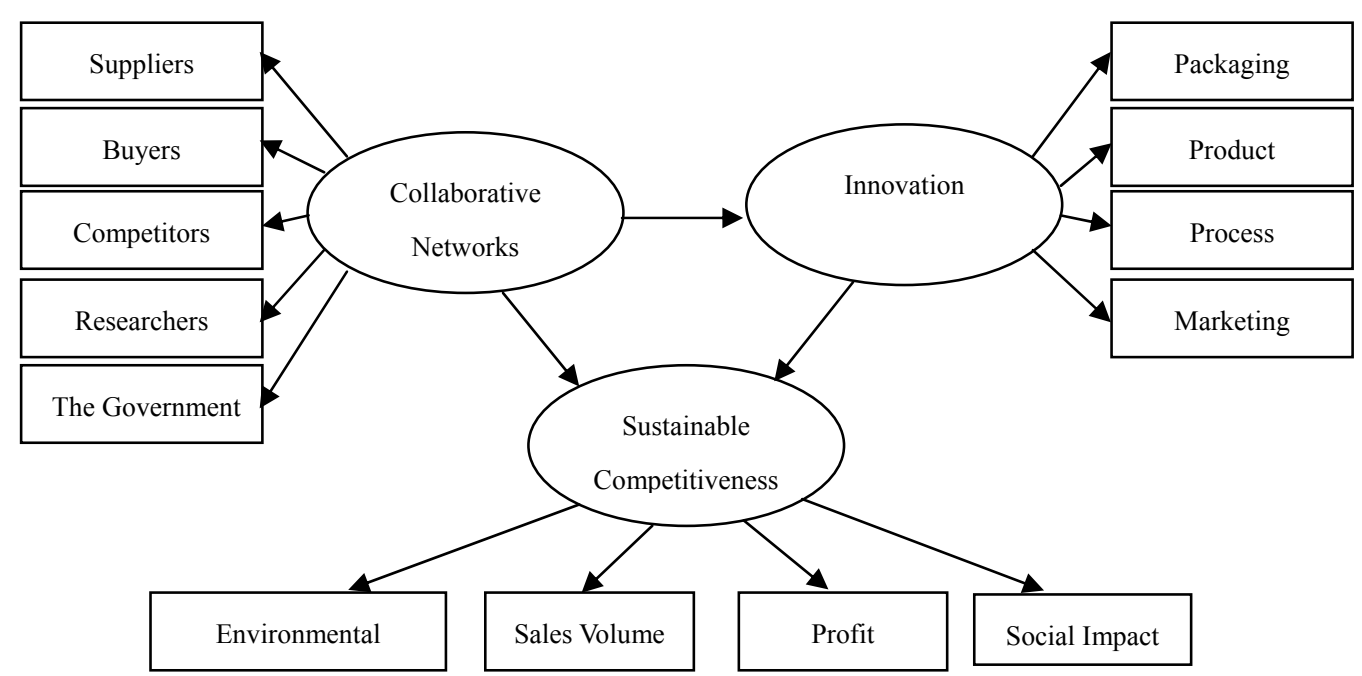

Figure 1. The structural model of the relationship between collaborative networks, innovation, and competitiveness

\section{Materials and Method}

\subsection{Sample and Data Collection}

The samples in this study were collected using the purposive sampling method in which the researchers select the samples based on certain criteria which have been pre-determined. The samples taken in this study have these criteria: 1. Small and Medium Enterprisesin food processing, 2. Possess innovation, 3. Have collaborated with other parties, 4. Have been established for at least 3 years. Completion of the questionnaires and in-depth interviews were conducted to discover the relationships between collaborative networks, innovation and sustainable competitiveness.

\subsection{Measurement Data Analysis}

Structural Equation Model (SEM) analysis was used to discover the relationships between the endogenous and exogenous variables. In this study, the relationships between the variables of Collaborative Networks, Innovation, and Sustainable Competitiveness will be assessed. The data collected were analyzed using the SEM with Partial Least Square (PLS) to obtain the Small and Medium Enterprises development model from the variabel Collaborative Networksand Innovation point of view.

\section{Results and Discussion}

\subsection{The Characteristics of the Respondents}

The respondents in this study are the actors in Small and Medium Enterprises that possess innovation developing their businesses, especially those in the food processing business around Bogor, Sukabumi, and Bandung districts. The number of respondents who have been interviewed is 40 respondents having various backgrounds. Sample selection was based on the innovation done, whether it is product innovation, packaging innovation, marketing innovation, or production innovation. Therefore, there are some Small and Medium Enterprises which had innovation in their product only, or in their packaging only, or in the marketing only, or a combination of the four possible innovations. The characteristics of the respondents were classified based on the gender, age, education, and how long they have operated their businesses (see Table 1). 
Table 1. The characteristics of the respondents

\begin{tabular}{|c|c|c|c|}
\hline No & Respondent characteristics & Number & $\%$ \\
\hline \multirow[t]{3}{*}{1} & Gender & & \\
\hline & Male & 22 & 55 \\
\hline & Female & 18 & 45 \\
\hline \multirow[t]{5}{*}{2} & Age & & \\
\hline & 17-25 years old & 1 & 2.5 \\
\hline & 26-35 years old & 3 & 7.5 \\
\hline & $36-45$ years old & 8 & 20 \\
\hline & $>45$ years old & 28 & 70 \\
\hline \multirow[t]{7}{*}{3} & Education & & \\
\hline & Elementary school & 6 & 15 \\
\hline & Junior High School & 6 & 15 \\
\hline & Senior High School & 8 & 20 \\
\hline & Diploma & 3 & 7.5 \\
\hline & Bachelor & 16 & 40 \\
\hline & Master & 1 & 2.5 \\
\hline \multirow[t]{4}{*}{4} & Business establishment & & \\
\hline & $1-3$ years & 12 & 30 \\
\hline & $4-5$ years & 4 & 10 \\
\hline & $>5$ years & 24 & 60 \\
\hline
\end{tabular}

The reason why they own the business is important to discover because it is closely related to the innovations that might arise during the business duration. Most of the respondents' reason for establishing the business is because it is lucrative (see Figure 2). Because of this reason, most of the respondents depend on their businesses as their livelihood. Due to the fact that they rely solely on their businesses, the actors will strive to develop their businesses, giving rise to innovation in their businesses.

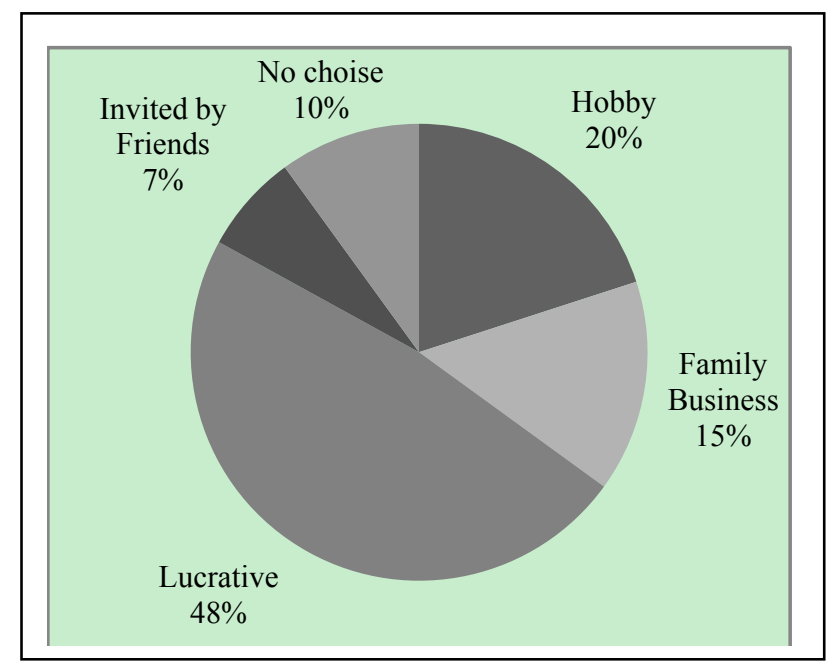

Figure 2. The reason why the respondents chose their businesses

In relation to innovation, the emergence of new ideas, 60 percent of the actors often introduce new ideas to their businesses. Therefore, most actors have new ideas which in time will develop their enterprises. This means that many food processing Small and Medium Enterprise actors practice innovations which are developed from their 
ideas, hoping that they will help maintain and develop their businesses because the constant presence of innovations will keep the consumer interested and loyal to the products they turn out. Approximately 55 percent of the business actors have never considered switching businesses. The details can be seen in Table 2 .

Table 2. The percentage of the emergence of new ideas and the thought of switching businesses

\begin{tabular}{lcc}
\hline & Intensity & Percentage (\%) \\
\hline The emergence of new ideas & Always & 15 \\
& Often & 60 \\
& Rarely & 25 \\
\hline The thought of switching businesses & Often & 17 \\
& Rarely & 28 \\
& Never & 55 \\
\hline
\end{tabular}

\subsection{Model Testing}

The data analysis was used to explain the effect of Collaborative Networks to Innovationon and Sustainable Competitiveness, using the Partial Least Square (PLS). PLS was first developed by Herman Wold. It was developed as an alternative to structural equation modeling which have weak theoretical bases. PLS can be used for confirming theories (theoretical testing) as well as for recommending relationships which have no theoretical bases (exploratory). In this study, the inner model and outer model were arranged based on previous theories and studies and the empirical condition in the field. In the end, research variables as seen in Table 3 were obtained.

Table 3. The research variables based on PLS analysis

\begin{tabular}{llll}
\hline $\begin{array}{l}\text { Endogenous Latent } \\
\text { Variables }(\boldsymbol{\eta})\end{array}$ & $\begin{array}{l}\text { Exogenous Latent } \\
\text { Variables }(\xi)\end{array}$ & Indicator X & Indicator Y \\
\hline & Collaborative & Supplier (x1) & \\
& Network $\left(\xi_{1}\right)$ & $\begin{array}{l}\text { Buyer (x2) } \\
\text { Competitor (x3) }\end{array}$ & \\
& Researcher (x4) & \\
& Government (x5) & \\
\hline Innovation $\left(\eta_{1}\right)$ & & Product (y1) \\
& & Packaging (y2) \\
& & Production process (y3) \\
& & Marketing (y4) \\
\hline Sustainable & & Competitiveness 1 (y5) \\
competitiveness $\left(\eta_{2}\right)$ & & Competitiveness 2 (y6) \\
& & Competitiveness 3 (y7) \\
& & Competitiveness 4 (y8) \\
\hline
\end{tabular}

\subsubsection{Measurement Model (Outer Model)}

According to Ghozali (2006), the measurement model or outer model analyzes the relationship between every indicator block (manifest) and its latent variable (construct). The analysis of the outer model can be seen from: composite reliability, indicator reliability, AVE, discriminant validity, and cross loading.

\subsubsection{Composite Reliability}

Composite reliability is a measurement of reliability of indicator blocks which measure the constructs. All the constructs in Table 4 have high composite reliability, above 0.6 as required. Therefore, it can be said that all the constructs are reliable in predicting the indicators within their blocks. 
Table 4. The latent variable composite reliability value

\begin{tabular}{lc}
\hline \multicolumn{1}{c}{ Variabel } & Composite Reliability \\
\hline Collaborative Network & 0.773719 \\
Sustainable Competitiveness & 0.729000 \\
Innovation & 0.825798 \\
\hline
\end{tabular}

As with composite reliability, the loading factors found in each indicator compared to their constructs were between 0.6-0.7. This value is still tolerable as long as it is still within the development phase, even though the recommended loading factor value is above 0.7 . Details pertaining to the indicator loading factor value can be seen in Table 5.

Table 5. The outer model values for each research indicator

\begin{tabular}{lccc}
\hline & $\begin{array}{c}\text { Collaborative } \\
\text { Network }\end{array}$ & $\begin{array}{c}\text { Sustainable } \\
\text { Competitiveness }\end{array}$ & Innovation \\
\hline Supplier & 0.802457 & & \\
Buyer & $\mathbf{0 . 0 7 3 2 8 3}$ & & \\
Government & 0.577132 & & \\
Researcher & $\mathbf{0 . 4 1 6 4 6 4}$ & & 0.777219 \\
Competitor & 0.705447 & 0.584231 \\
Packaging innovation & & & 0.838398 \\
Marketing innovation & & 0.730632 \\
Product innovation & & & \\
Process innovation & & 0.413103 & \\
Profit & & 0.715355 & \\
Environment & & 0.834197 & \\
Community & & 0.478964 & \\
Market share & & & \\
\hline
\end{tabular}

Based on Table 5, it can be seen that almost all the indicators have a loading value of more than 0.5 , but there are two indicators which have values less than 0.5 , collaborative network with buyers and collaborative network with researchers and the profit indicator in the sustainable competitiveness variable. The three indicators were no longer included in the following processes.

\subsubsection{Reliability Indicator}

Another test to evaluate the outer model was using Cronbach's alpha value from the block indicator for measuring construct. The output results related to the Cronbach's alpha values can be seen in Table 6 .

Table 6. The Cronbach's Alpha value of latent variables

\begin{tabular}{lc}
\hline \multicolumn{1}{c}{ Variabel } & Cronbachs Alpha \\
\hline Collaborative Network & 0.589737 \\
Sustainable Competitiveness & 0.534547 \\
Innovation & 0.729561 \\
\hline
\end{tabular}

From Table 6, it is seen that the Cronbach's alpha value of collaborative network and sustainable competitiveness are less than 0.7 ; however, seen from the composite reliability (Table 5), the value for each indicator is more than 0.7 , therefore they are still considered reliable. 


\subsubsection{AVE and Discriminant Validity}

The recommended AVE value is more than 0.5. The measurement in that particular construct block is better than the measurement in other construct blocks. The results of the study show that all constructs have an AVE root as large as the other constructs and the value of most of the AVE roots (diagonal) is larger than the correlation among variables. This indicated that the constructs have relatively high discriminant validity. For more detail about the AVE value and the AVE roots, see Table 7, and for the Fornell-Larcker discriminant validity value, see Table 8.

Table 7. The AVE value of latent variables

\begin{tabular}{lll}
\hline & AVE & $\sqrt{A V E}$ \\
\hline Collaborative Network & 0.540743 & 0.735 \\
Sustainable Competitiveness & 0.411293 & 0.693 \\
Innovation & 0.546514 & 0.739 \\
\hline
\end{tabular}

Table 8 . The mode value with the Fornell-Larcker discriminant validity

\begin{tabular}{lccc}
\hline & Collaborative Network & Sustainable Competitiveness & Innovation \\
\hline Collaborative Network & $\mathbf{0 . 7 3 5 0 0 0}$ & & \\
Sustainable Competitiveness & 0.454621 & $\mathbf{0 . 6 9 3 0 0 0}$ & \\
Innovation & 0.376023 & 0.529670 & $\mathbf{0 . 7 3 9 0 0 0}$ \\
\hline
\end{tabular}

\subsubsection{Cross Loading}

The purpose for determining discriminant validity is to prove that the latent constructs are better in predicting the measurement within their own blocks than in predicting the measurements in other blocks. If the construct correlation value with the measurement item is larger than the correlation values with other constructs, it shows that the latent construct predicts the measurement in its own block better than the measurements in other blocks. From Table 9 it can be seen that all indicator correlations to latent variables are higher than the correlations to other latent variables; therefore validity is fulfilled in accordance to the indicator requirement that the indicator has a higher correlation with its own latent variable than with other latent variables.

Table 9. Discriminant validity analysis-cross loading

\begin{tabular}{lccc}
\hline & Collaborative Network & Competitiveness Berkelanjutan & Innovation \\
\hline Supplier & $\mathbf{0 . 8 8 4 0 3 4}$ & 0.497877 & 0.338134 \\
Government & $\mathbf{0 . 5 6 1 8 7 4}$ & 0.137058 & 0.346314 \\
Competitor & $\mathbf{0 . 7 2 4 5 7 6}$ & 0.251830 & 0.077230 \\
Packaging Innovation & 0.266251 & 0.291136 & $\mathbf{0 . 7 7 8 2 3 8}$ \\
Marketing Innovation & 0.261147 & 0.190505 & $\mathbf{0 . 5 7 7 2 7 0}$ \\
Product Innovation & 0.405060 & 0.532364 & $\mathbf{0 . 8 3 2 5 1 3}$ \\
Process Innovation & 0.132278 & 0.443597 & $\mathbf{0 . 7 4 4 3 6 7}$ \\
Environment & 0.416674 & $\mathbf{0 . 7 0 8 7 5 9}$ & 0.198299 \\
Community & 0.408296 & $\mathbf{0 . 8 1 8 7 3 5}$ & 0.461550 \\
Market Share & 0.079901 & $\mathbf{0 . 5 1 9 4 1 7}$ & 0.416107 \\
\hline
\end{tabular}

\subsubsection{Structural Model (Inner Model)}

The structural model which is also known as the inner model depicts the relationship between latent variables based on the substantive theory. Evaluation of the inner model can be done by observing the structural model 
which consists of relationships that are hypothesized between the latent constructs in the research model. By using the Bootstrapping method on Smart PLS, the standard errors, path coefficients/S, and t-statistic values could be obtained. Using this technique, the researchers can assess the statistical significance of the research model by testing the hypotheses for each relationship path.

\subsubsection{Path Coefficient Estimation}

The bootstrapping results shown on Table 10 shows the coefficient for each hypothesis path and the t-statistic value which is obtained from the Smart PLS result output as follows:

Table 10. The results of the bootstrapping of each indicator weight toward latent variables

\begin{tabular}{|c|c|c|c|c|c|}
\hline & $\begin{array}{c}\text { Original } \\
\text { Sample (O) }\end{array}$ & $\begin{array}{c}\text { Sample } \\
\text { Mean (M) }\end{array}$ & $\begin{array}{l}\text { Standard } \\
\text { Deviation } \\
\text { (STDEV) }\end{array}$ & $\begin{array}{c}\text { Standard } \\
\text { Error } \\
\text { (STERR) }\end{array}$ & $\begin{array}{l}\text { t-statistics } \\
\text { (|O/STERR|) }\end{array}$ \\
\hline Collaborative Networks & 0.297520 & 0.299455 & 0.279681 & 0.279681 & 1.063785 \\
\hline \multicolumn{6}{|c|}{-->Sustainable Competitiveness } \\
\hline Collaborative Networks & 0.376023 & 0.429901 & 0.126602 & 0.126602 & $2.970119^{*}$ \\
\hline \multicolumn{6}{|l|}{-->Innovation } \\
\hline Innovation-->Sustainable & 0.417796 & 0.414324 & 0.215974 & 0.215974 & $1.934469^{* *}$ \\
\hline Competitiveness & & & & & \\
\hline
\end{tabular}

In Table 10, it can be seen that Collaborative Networks has a direct, positive effect on Innovation with a path coefficient of 0.376 and is significant at $p \leq 0.05$. The Innovation variable has a direct, positive effect on Sustainable Competitiveness with a path coefficient of 0.417 and is significant at $\mathrm{p} \leq 0.10$ (t-statistic (1.93) $>\mathrm{T}$ Table 1.64). On the other hand, the Collaborative Networks has no direct effect on Sustainable Competitiveness, the direct path value is 0.29 and is significant at $\mathrm{p}>0.10$ (t-statistic $<\mathrm{T}$ Table 1.64).

\subsubsection{R-Square}

The model's explanatory poweror its nomological validity can be assessed by observing the $R$-square $\left(\mathrm{R}^{2}\right)$ value of the endogenous constructs or the dependent variables: the innovationvariable and the sustainable competitive variable. The R-Square value is used to assess the effect of certain latent independent variables on dependent latent variables.

Table 11. The R-square value of latent variables

\begin{tabular}{lc}
\hline & R Square \\
\hline Collaborative Network & - \\
Sustainable Competitiveness & 0.356553 \\
Innovation & 0.141393 \\
\hline
\end{tabular}

Table 11 shows that the value of $\mathrm{R}^{2}$ of the sustainable competitiveness variable is 0.356 . This means that the Collaborative Networks and Innovation variables can simultaneously explain the variability of the Sustainable Competitiveness of $35.6 \%$, while $64.4 \%$ is explained by another variable. The value of the Innovation variable $\mathrm{R}^{2}$ is 0.141 which means that the Collaborative Networks variable is able to explain the variability of the Innovation variable of $14.1 \%$, whereas $85.9 \%$ is explained by another variable. Figure 30 depicts the PLS estimate model of the research model which shows the variance $\left(R^{2}\right)$ in dependent constructs and the path coefficients and their significance using an asterisk $(*)$. 


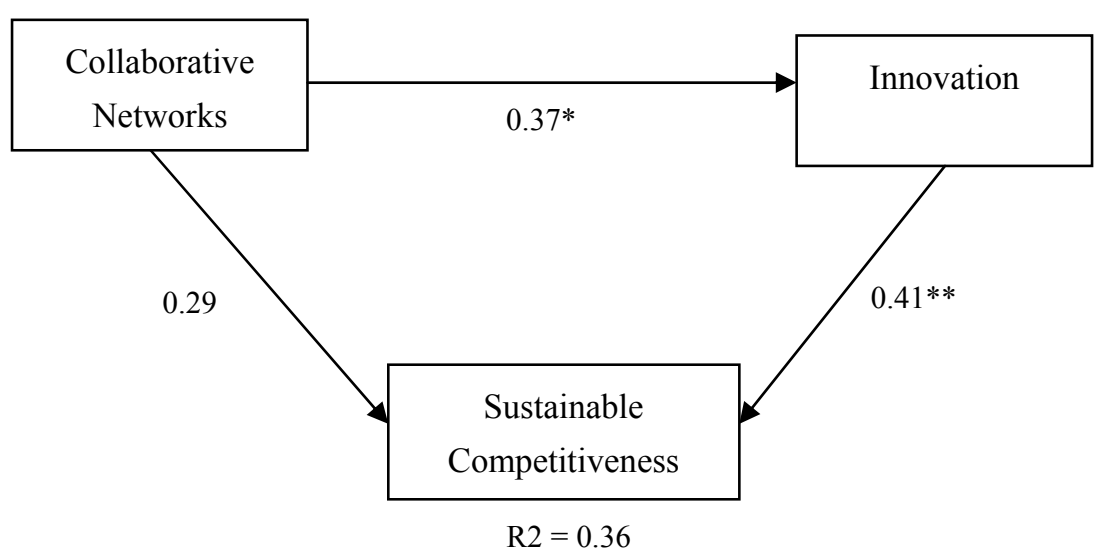

\subsection{Research Model}

Figure 3. The study result model

Based on the research model analysis using PLS, an initial research model which is presented in Figure 4 was obtained. The final research model is presented in Figure 5.

\subsubsection{The Effect of Collaborative Networks on Innovation}

The results of the testing using PLS show that the effect of Collaborative Networks on Innovation (original sample estimate 0.376 , t-test value 2.970) is significant. The correlation coefficient between Collaborative Networks and innovation is 0.376 , which in this case is categorized as a weak correlation. In other words, if there is an increase in the role of Collaborative Networks, it will increase Innovation. With the Collaborative Networks variable, the indicator which is best able to represent it is the supplier, followed by the competitors and the government.

Collaborative Networks in this study consists of the roles of the suppliers, buyers, government, researchers, and competitors. In this study about Small and Medium Food Processing Enterprises in West Java Indonesia, it can be seen in the PLS results (Figure 3). The results of this study show that there is a positive relationship between colloborative networks and product innovation in Small and Medium Food Processing Enterprises in West Java. Innovation is the most important factor in increasing internal competitiveness, especially in Small and Medium Food Processing Enterprises which must compete with both other Small and Medium Food Processing Enterprises and large industries. Small and Medium Food Processing Enterprises in West Java have developed several innovations in developing their food products. For instance, the Mochi cake-producing Small and Medium Enterprises in Sukabumi developed their product innovation by creating a variety of flavors; whereas in the past the only filling was peanuts, nowadays they have chocolate, cheese, and durian fillings. In addition, they have also developed the packaging. Previously, the packaging was woven bamboo boxes. Now, they use cardboard boxed printed to look like woven bamboo or packaging that represented the mochi's flavor which come in various sizes. In Bogor, this kind of innovation can be seen in the Chocolate-producing Small and Medium Enterprises. These Small and Medium Enterprises have applied innovation to their products, packaging, process, and marketing. 


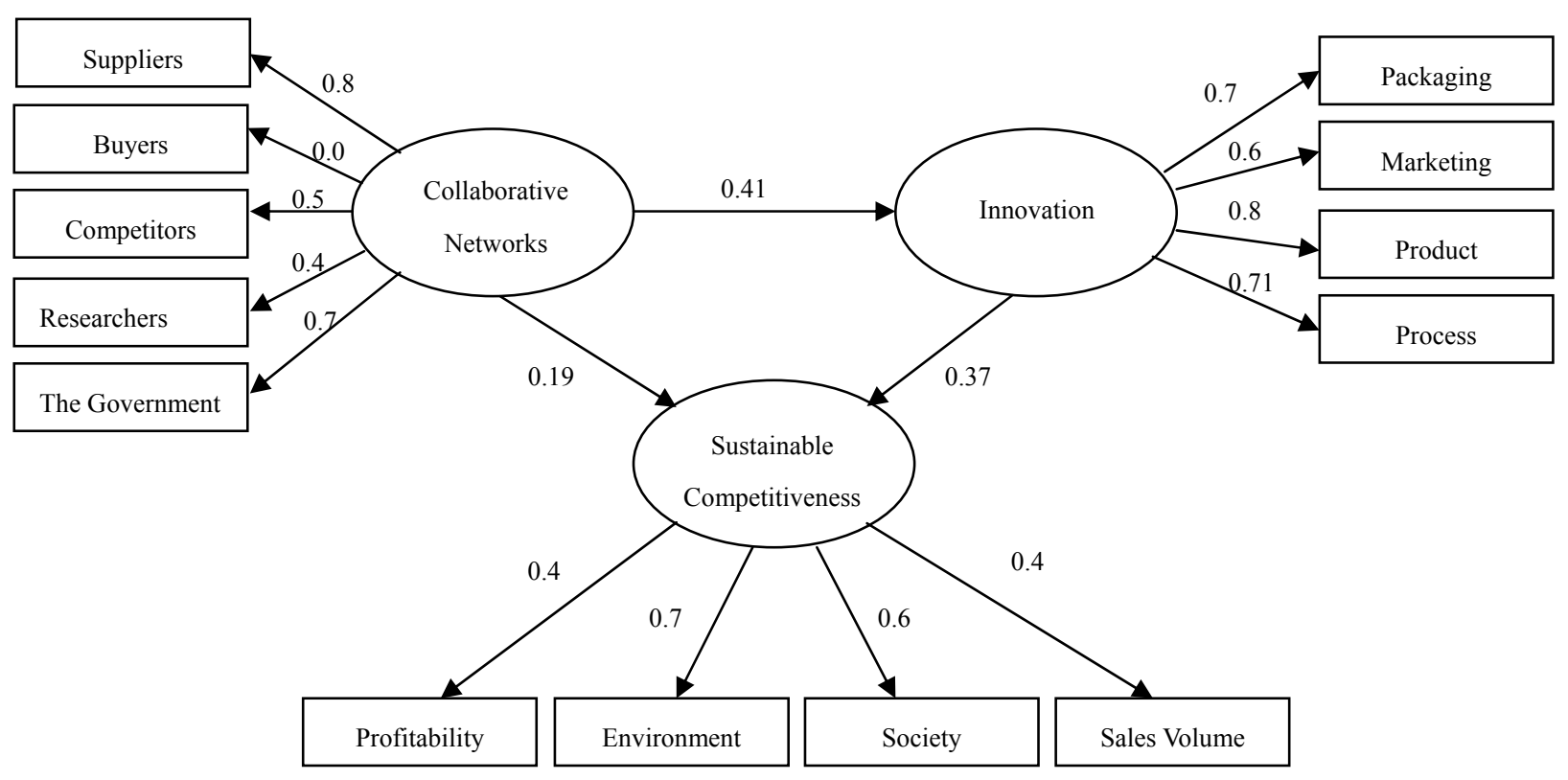

Figure 4. The results of the initial research model

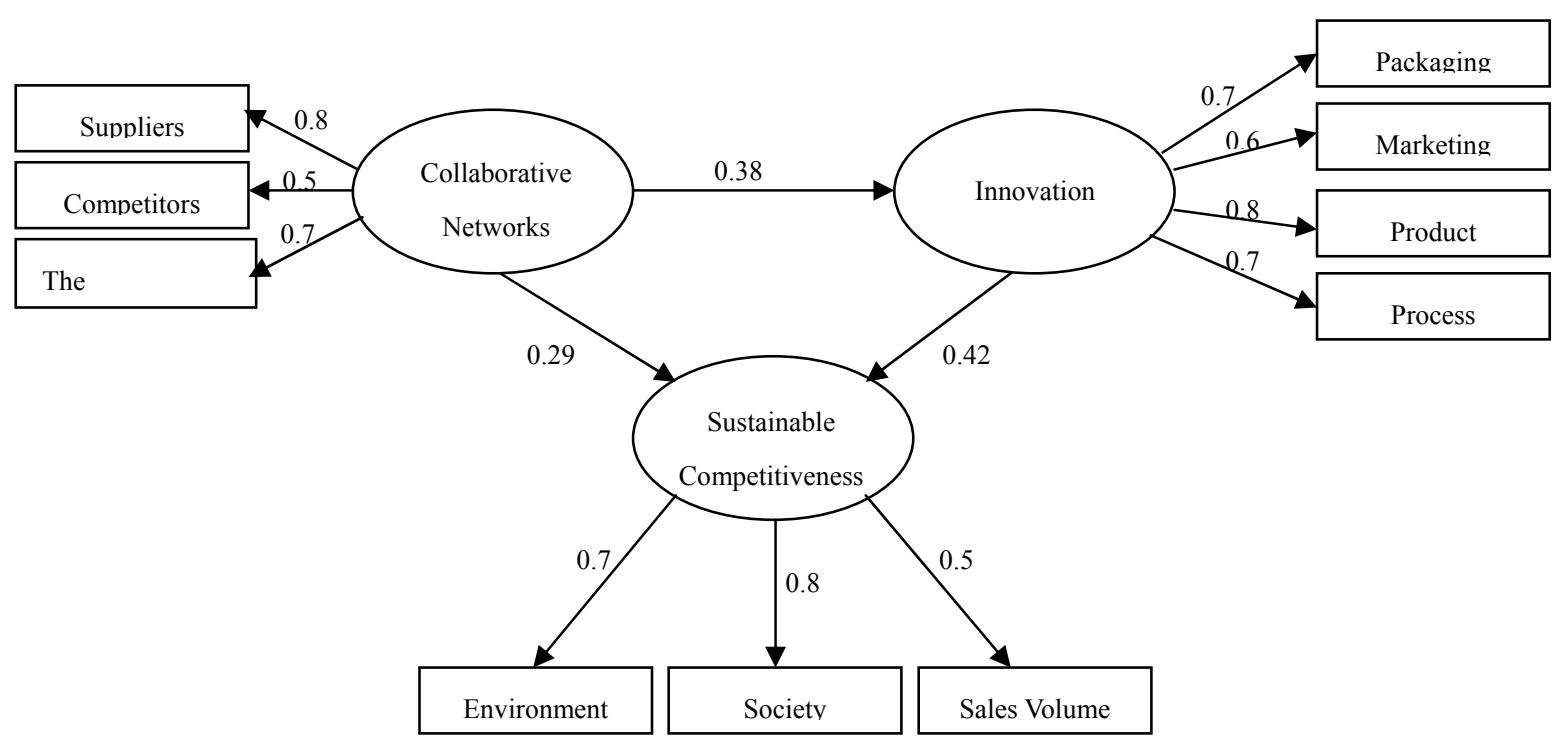

Figure 5. The results of the final research model

The innovations made by several Small and Medium Food Processing Enterprises in West Java cannot be separated from the roles of the suppliers, competitors, the government, buyers, and researchers as a unity in a collaborative network. In the study of Small and Medium Enterprisesin West Java, it was discovered that the roles of the supplier, competitor, and government influence the development of product innovation in Small and Medium Enterprises. Suppliers determine the availability of raw ingredients in food processing. If the ingredients are not continuously supplied, the innovations in product, process, packaging, and marketing cannot be done. Competitors encourage innovation in food processing Small and Medium Enterprises. The presence of competitors means that Small and Medium Food Processing Enterprises will strive to come up with innovations in product, process, packaging, or marketing. The Small and Medium Food Processing Enterprises will compete among themselves to give their products a distinct character to their products. This was seen in the Mochi industry in Sukabumi district. The owners of different Mochi factories which were located near one another created their own innovations, for example in flavor variation or in the packaging. In Bogor, the cake industry has created a uniquely different cake from the ones usually sold. Bogor is famous as a taro producing area, creating an opportunity for Small and Medium Food Processing Enterprises to create a taro-based cake. Besides the cake, other Small and Medium Food Processing Enterprises also created other innovations which embodied 
Bogor as a taro producing area such as taro pia cakes. All of these were done by Small and Medium Food Processing Enterprises in order to survive in the middle of the food industry which is growing more and more competitive, especially in West Java.

Besides suppliers and competitors, the government also holds an important role in the development of innovations done by the Small and Medium Food Processing Enterprises in West Java. Government policies to hold exhibitions and hold training programs for small and medium enterprises working in the food processing industry could encourage Small and Medium Enterprises to be more innovative in creating food products. The government through state-owned banks and private banks also encourage the Small and Medium Food Processing Enterprises to innovate by providing fresh funds for their product development.

The roles of the researchers and buyers in this study of Small and Medium Food Processing Enterprises in West Java did not have any effect on innovation growth. This was because the innovations made by the Small and Medium Food Processing Enterprises developed when they were pushed by the products churned out of competitors. Studies rarely provide practical strategies for the innovation of a product of food processing Small and Medium Enterprises; they more often provide marketing development and financial management assistance. Even if there are any studies for innovations in the product, process, or packaging, they are still hampered by the lack of funds. Buyers also lack any function as a driving force for Small and Medium Enterprises innovation in West Java. Small and Medium Food Processing Enterprises believe that if their products have a distinctive characteristic, buyers will still seek out their products.

\subsubsection{The Effect of Collaborative Networks on Sustainable Competitiveness}

The relationship between Collaborative Networks and Sustainable Competitiveness in this study is very singular. Even though Small and Medium Enterprises need collaboration to overcome various obstacles in innovation, Collaborative Networks has no direct impact on the Sustainable Competitiveness of Small and Medium Food Processing Enterprises in West Java (original sample estimate 0.297, t-test value1.064). The value of the correlative coefficient between Collaborative Networks and Sustainable Competitiveness is classified as a low correlation.

Collaborative Networks have a very important role in the development of innovations made by Small and Medium Food Processing Enterprises in West Java. As commonly known, the development of innovations made by Small and Medium Enterprises are as a means to survive in their industry. In other words, Small and Medium Enterprisesmust keep innovating or modifying their products in order to respond the market's demands. The effort done by Small and Medium Enterprises is maintaining collaboration with the suppliers and the government. To encourage innovation, Small and Medium Enterprises also keep their eyes on their competitors.

In this study of Small and Medium Food Processing Enterprises in West Java, it was discovered that Collaborative Networks have no direct impact on Sustainable Competitiveness as profit, market share, environment, and the community (social impact) do. However, this does not mean that Collaborative Networks have no role at all in food processing Small and Medium Enterprises' sustainable competitiveness in West Java. Collaborative Networks still have an effect on Sustainable Competitiveness through the development of innovations made by the companies, especially collaborations with suppliers, competitors, and the government.

\subsubsection{The Effect of Innovation on Sustainable Competitiveness}

The results of this study show that the Innovation variable has a positive impact on Sustainable Competitiveness (original sample estimate 0.417 ; t-test value 1.934). The value of the correlation coefficient between Innovation and Sustainable Competitiveness is 0.417 . This correlation is classified as a medium relationship. For the Innovation variable, the indicators which reflect it are, respectively, community competitiveness, environmental competitiveness, and market share competitiveness.

Innovation is the Small and Medium Enterprises' effort to increase productivity and competitiveness. In this study, it was discovered that the innovations made by Small and Medium Food Processing Enterprises in West Javacan affect the increase in sustainable competitiveness. The innovations made are in the form of product, packaging, proses, and marketing innovations. The majority of Small and Medium Food Processing Enterprises in West Javahave practiced productand packaging innovation. Product innovations are carried out through flavor, shape, ingredient (taro cake) variations. Packaging innovations are making different sizes of packaging and changing the packaging materials. For example, Mochi, which used to be packed in woven bamboo boxes, is now packed in cardboard boxes printed to look like woven bamboo. Chocolate producing Small and Medium Enterprises in Bogor use recycled paper to pack their goods. Some Small and Medium Enterprises have conducted marketing innovation, i.e., marketing via the Internet, printing brochures, and renovating their outlets 
to create product images (for example the mochi Lamphion production house). Small and Medium Food Processing Enterprises in West Java have minimum process innovation because they are hindered by the lack of funds to purchase production equipment. Besides, many Small and Medium Food Processing Enterprises still use traditional processes.

\section{Conclusion}

This study address importance issue related to sustainable competitiveness of SMEs in Indonesia as an emerging market. The result of the study gives the fact that the variable of collaborative networks and innovation should be considered as important factors to develop sustainable competitiveness in Indonesian SMEs, especially in Small and Medium Food Processing Enterprises.

In this study, variable of collaborative network has an effect on the innovations made by Small and Medium Food Processing Enterprises in West Java, particularly the roles held by suppliers, competitors, and the government, whereas the roles of the researchers and buyers encourage food processing Small and Medium Enterprises' innovationin West Java. Collaborative network has no effect on sustainable competitiveness in Small and Medium Food Processing Enterprises in West Java; however, innovation will increase sustainable competitiveness. The innovations made by Small and Medium Food Processing Enterprises in West Java will increase sustainable competitiveness.

Even though the result of this study was able to prove the hypothesis of research, this study still has some limitations. First, these interesting findings are limited to the case of Indonesia. Therefore, the findings of this study are worthy of examination in other contexts. Second, the data collected by purposive sampling method and small number of sample make this result cannot be generalized. It can be improved by random sampling method with larger number of sample.

\section{Acknowledgement}

The Authors are very grateful to two anonymous referees who gave us helpful comments to improve this paper. The Authors also express their gratitude for the support by Ministry of Education and Culture of Republic of Indonesia (Grant-in-Aid for Fundamental Research No. 260/IT3.41.2/L2/SPK/2013).

\section{References}

BarNir, A., \& Smith, K. A. (2002). Interfirm Alliances in the Small Bussiness: The Role of Social Network. Journal of Small Bussiness Management, 40(3), 219-232. http://dx.doi.org/10.1111/1540-627X.00052

Ceglie, G. (2003). Cluster and Network Development: Examples and Lessons from UNIDO Experience. Conference on Cluster Industrial Districts and Firms: The Challenge of Globalization.

Das, S. C. (2013). Small and Medium Food Processing Units in Odisha: An Empirical Study on Competitiveness. Srusti Management Review, 6(1), 11-16.

Datar, S., Jordan, C. C., Kekre, S., Rajiv, S., Srinivasan, K. (1997). Advantages of time based new development in a fast cycle industry. Journal of Marketing Research, 34(1), 36-49. http://dx.doi.org/10.2307/3152063

Hamdani, J., \& Wirawan, C. (2012). Open Innovation Implementation to Sustain Indonesia SMEs. International Conference on Small and Medium Enterprises Development with a Theme "Innovation and Sustainability in SME Development" (ICSMED 2012). Procedia Economics and Finance, 4, 223-233.

Hanna, V., \& Walsh, K. (2002). Small Firm Networks: A Successful Approach to Innovation? R\&D Management, 32(2), 201-207. http://dx.doi.org/10.1111/1467-9310.00253

Kolakovic, M., \& Milovanovic, B. J. (2010). Strategic Networking as A Driver of Competitiveness of Croatian Small and Medium Enterprises. International Conference Proceedings, 9(13), 1213-1224.

Mezgar, I., Kovacs, G. L., \& Paganelli, P. (2000). Co-operative Production Planning for Small and Medium-Sized Enterprises. International Journal of Production Economics, 64(1), 37-48.

Munir, A., Lim, M. K., \& Knight, L. (2011). Sustaining Competitive Advantage ini SMEs. Procedia - Social and Behavioral Sciences, 25, 408-412. The 2011 International (European) Conference on Asia Pacific Business Innovation \&Technology Management.

Sakamoto, A. R., Roper, S., Vasconcellos, M. A., \& Gobbo, A. (2010). Innovation in Collaborative Networks of Small and Medium Enterprises: An Interpretative Approach. World Conference Proceedings, 1-20. Washington: International Council for Small business (ICSB). 
Sundbo, J. (2003). Innovation and Strategic Reflexivity: An Evolutionary Approach Applied to Service. The International Handbook on Innovation.

Tsai, K. H. (2009). Collaborative Networks and Product Innovation Performance. Research Policy, 38(5), 765-778. http://dx.doi.org/10.1016/j.respol.2008.12.012

Varrichio, P., Diogenes, D., Jorge, A., \& Garnica, L. (2012). Collaborative Network and Sustainable Bussiness: A Case Study in The Brazilian System of Innovation. 10th Triple Helix Conference 2012. Procedia-Social and Behavioral Sciences, 52, 90-99. http://dx.doi.org/10.1016/j.sbspro.2012.09.445

Zeng, S. X., Xie, X. M., \& Tam, C. M. (2010). Relationship between Cooperation Network and Innovation Performance of SMEs. Technovation, 30, 181-194. http://dx.doi.org/10.1016/j.technovation.2009.08.003

\section{Copyrights}

Copyright for this article is retained by the author(s), with first publication rights granted to the journal.

This is an open-access article distributed under the terms and conditions of the Creative Commons Attribution license (http://creativecommons.org/licenses/by/3.0/). 